\title{
Surge propagation constrained by a persistent subglacial conduit, Bakaninbreen-Paulabreen, Svalbard
}

\author{
Douglas I. BENN, ${ }^{1,2}$ Lene KRISTENSEN, ${ }^{1}$ Jason D. GULLEY ${ }^{1,3}$ \\ ${ }^{1}$ The University Centre in Svalbard (UNIS), Box 156, NO-9171 Longyearbyen, Norway \\ E-mail: doug.benn@unis.no \\ ${ }^{2}$ Department of Geography and Geosciences, University of St Andrews, St Andrews KY16 9AL, UK \\ ${ }^{3}$ Department of Geological Sciences, University of Florida, 241 Williamson Hall, PO Box 112120, \\ Gainesville, FL 32611, USA
}

\begin{abstract}
Glacier surges tend to be initiated in relatively small regions, then propagate down-glacier, up-glacier and/or across-glacier. The processes controlling patterns and rates of surge propagation, however, are incompletely understood. In this paper, we focus on patterns of surge propagation in two confluent glaciers in Svalbard, and examine possible causes. One of these glaciers, Bakaninbreen, surged in 1985-95. The surge propagated $\sim 7 \mathrm{~km}$ down-glacier, but did not cross the medial moraine onto the other glacier, Paulabreen. When Paulabreen surged between 2003 and 2005, the surge wave travelled several $\mathrm{km}$ down-glacier, but its lateral boundary stayed very close to the medial moraine. The confluent glaciers formerly extended into a fjord, and bathymetric mapping and historical observations show that an active subglacial conduit has existed between Bakaninbreen and Paulabreen since at least the early 20th century. The existence of a persistent subglacial conduit below the medial moraine was confirmed when we entered and mapped a Nye channel at the confluence of Bakaninbreen and Paulabreen. We argue that the conduit acts as a barrier to surge propagation. If pressurized water below one branch of the glacier system reaches the conduit, water can be readily evacuated, preventing its propagation into the other branch.
\end{abstract}

\section{INTRODUCTION}

Surges of polythermal glaciers are thought to be initiated when cold regions of the glacier bed are raised to the pressure-melting point, and basal meltwater is produced more rapidly than it can be evacuated (Murray and others, 2000; Fowler and others, 2001). Following surge initiation, evolution of the glacier flow field and patterns of surge propagation can follow a variety of pathways. Surges of landterminating glaciers usually begin in the upper reservoir zone, then propagate down-glacier as a kinematic wave (e.g. Meier and Post, 1969), whereas some tidewater glacier surges have been observed to begin on the lower tongue, then propagate upstream (e.g. Luckman and others, 2002; Dowdeswell and Benham, 2003). Peak ice velocities and rates of surge propagation also vary widely between glaciers. Modelling work by Fowler and others (2001) has identified some of the factors that are likely to control patterns and rates of surge propagation, although observational data to support further model testing and development are still very sparse.

In this paper, we focus on patterns of surge propagation on Bakaninbreen and Paulabreen, two confluent glaciers in Svalbard. Both glaciers have surged within the last two decades, but in each case the surge affected only one branch of the glacier. We present geomorphological, historical and speleological evidence for a persistent subglacial drainage channel between the two glaciers, and argue that efficient drainage along this corridor served to limit lateral surge propagation.

\section{BAKANINBREEN AND PAULABREEN}

Bakaninbreen and Paulabreen are confluent glaciers that drain into the fjord of Rindersbukta, an arm of Van Mijenfjorden in central Spitsbergen (Fig. 1). In their lower reaches, the glaciers flow on either side of a prominent medial moraine extending northwest from their confluence below the nunatak Siggerudfjella. At the time of writing, most of the front of Paulabreen calves into Rindersbukta, whereas Bakaninbreen is entirely land-based. In 1898, the glaciers (which were then collectively known as Paula's Glacier) terminated close to the mouth of Rindersbukta (Kjellström, 1901; Ottesen and others, 2008). For the following century, the glaciers progressively calved back into the fjord, retreating $\sim 10 \mathrm{~km}$ between 1899 and 2003 . Bakaninbreen and Paulabreen surged in 1985-95 and 2003-05, respectively. The surge of Bakaninbreen terminated before the surge front reached the terminus, which remained inactive. In contrast, the surge of Paulabreen resulted in a terminus advance of $1.9 \mathrm{~km}$, temporarily reversing the retreat of ice in the fjord.

At the onset of the surge of Bakaninbreen, a steep ramp developed at the down-glacier boundary of fast-flowing ice, $\sim 8 \mathrm{~km}$ from the terminus (Dowdeswell and others, 1991). The ramp was $25 \mathrm{~m}$ high during the early stages of the surge, but grew to $60 \mathrm{~m}$ high as the surge propagated down-glacier during the next few years. Between 1985 and 1989, the rate of surge-front propagation varied between $\sim 1$ and $\sim 1.8 \mathrm{~km} \mathrm{a}^{-1}$, but after 1989 the rate progressively declined and by $1994 / 95$ was only $1.8-3.0 \mathrm{~m} \mathrm{a}^{-1}$ (Murray and others, 1998; Fig. 2). Although the surge front propagated downglacier for over $6 \mathrm{~km}$ and affected the whole width of the Bakaninbreen flow unit, it did not propagate laterally across the medial moraine onto Paulabreen. In addition, the medial moraine between the two glaciers underwent only very small lateral displacement during the surge, despite significant longitudinal strain of Bakaninbreen ice (Fig. 3a and b).

The mechanisms of surge propagation at Bakaninbreen have been studied in detail by Murray and others (1997, 


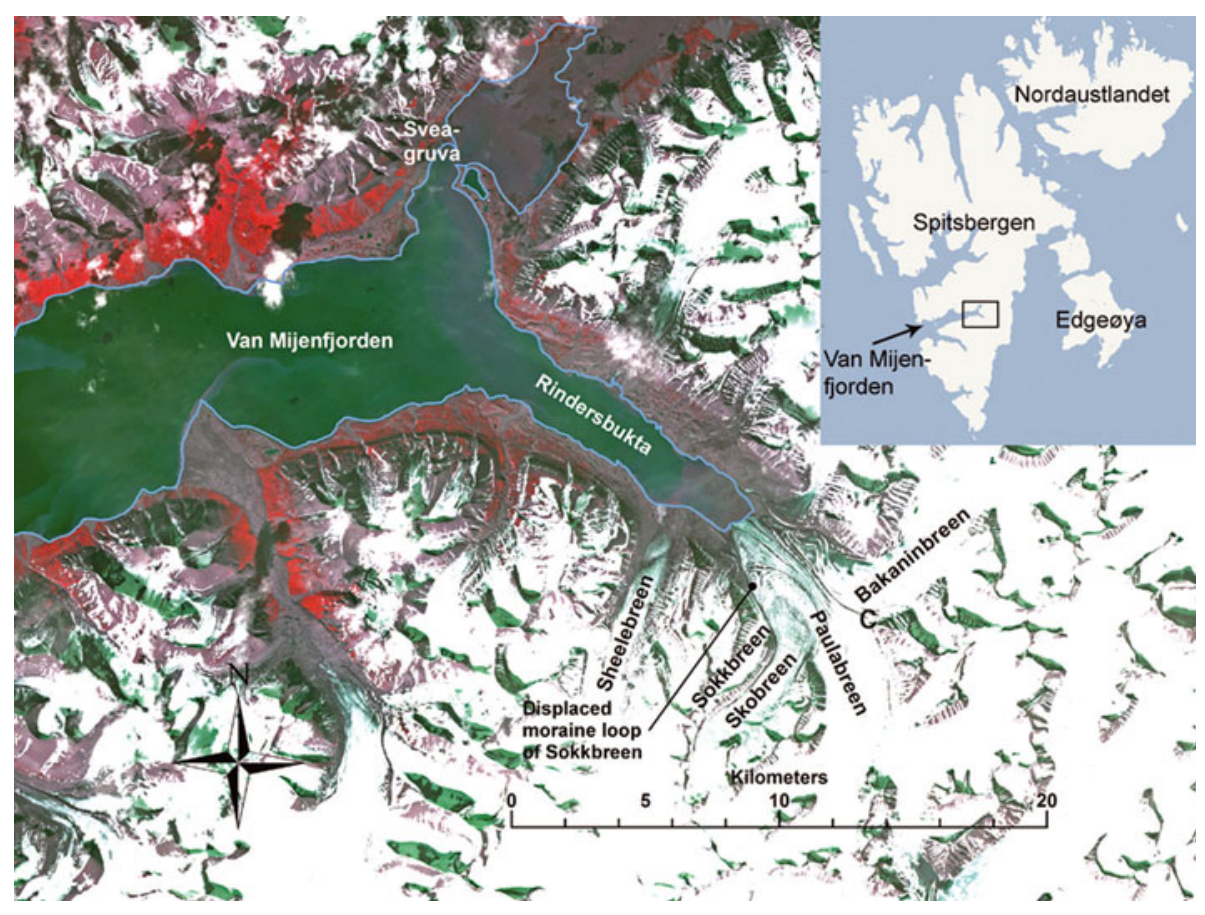

Fig. 1. Location of Bakaninbreen, Paulabreen and other places mentioned in the text shown on an ASTER image acquired in July 2005. The location of the Nye-channel entrance is labelled C.

1998, 2000) and Murray and Porter (2001). Radio-echo soundings in 1986 and 1996 and temperature measurements in 1994 and 1995 showed that the ice ahead of the surge front was frozen to the bed, whereas the rapidly flowing ice behind the front was warm-based, with the lowermost $\sim 40 \mathrm{~m}$ of the glacier at or very close to the pressure-melting point. The glacier bed consisted of a mixture of glaciomarine muds and glacial till, at least $0.2 \mathrm{~m}$ thick. Murray and others (2000) argued that these sediments did not completely thaw during the surge, and that basal water was trapped between the glacier sole and permafrost. The resulting elevated water pressures reduced the frictional strength of the bed, encouraging basal motion. Downglacier propagation of the surge bulge was also associated with longitudinal compression and vertical thickening of the ice, part of which was accommodated by brittle failure. Murray and others $(1997,2000)$ documented a series of

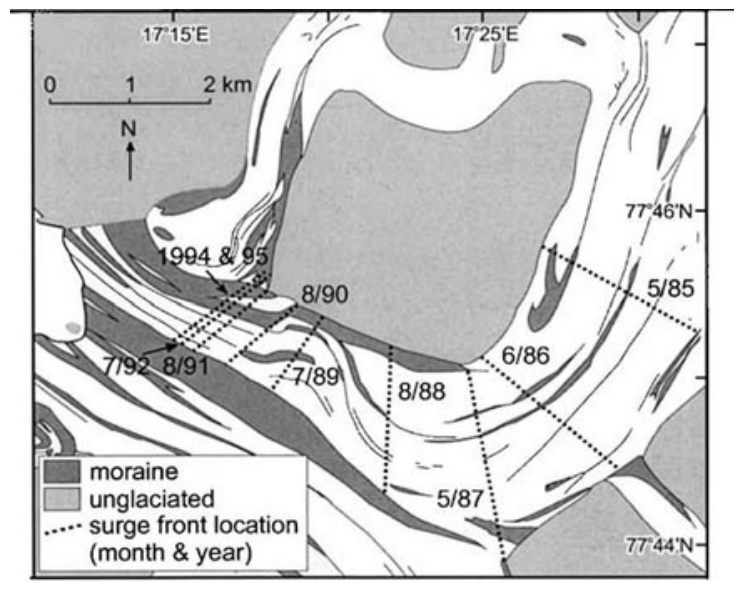

Fig. 2. Successive positions of the surge front of Bakaninbreen, 1985-95. (From Murray and others, 1998). coherent englacial structures dipping up-glacier at around $21-35^{\circ}$, both ahead of and behind the surge front, which were interpreted as thrust faults. Most of the structures terminated below the surface, but a few cropped out on the glacier surface, where they contained basal sediment and intermittently discharged pressurized water. Further evidence for brittle failure at the surge front was provided by analysis of seismic emission recordings made in 1987 (Stuart and others, 2005). Three distinct types of emissions were identified, interpreted as the result of shallow faulting up-glacier of the surge front, brittle failure of cold ice, and resonance in water-filled cracks ahead of the surge front. Propagation of the surge was therefore associated with thawing of the basal ice and the uppermost part of the bed, and down-glacier extension of the region affected by high basal water pressures. Water intermittently escaped from the bed to the surface along thrust faults, encouraging lower basal water pressures and heat loss from the bed. As a result, this 'leaky surge front' appears to have limited the rate of surge propagation and contributed to surge termination (Murray and others, 2000). Escape of water through gaps in the subglacial permafrost also appears to have played a role in surge termination (Smith and others, 2002).

The recent surge of Paulabreen originated in Skobreen, a tributary on the southwestern flank of the glacier (Fig. 1). The time of surge onset is not known, but the appearance of new crevasses in the upper part of Skobreen in 1990 suggests that the glacier may have undergone a long initiation phase prior to full onset (Sund, 2006). By summer 2003, most of Skobreen was affected by the surge, with a prominent surge bulge close behind the moraine loop where the glacier enters Paulabreen. At that time, ice in the upper part of Skobreen was drawn down and covered with transverse crevasses, and longitudinal crevasses were present on the surge bulge. Between 8 August 2003 and 3 April 2005 the surge propagated down-glacier and activated Paulabreen as far as its terminus. The mean rate of surge propagation was 

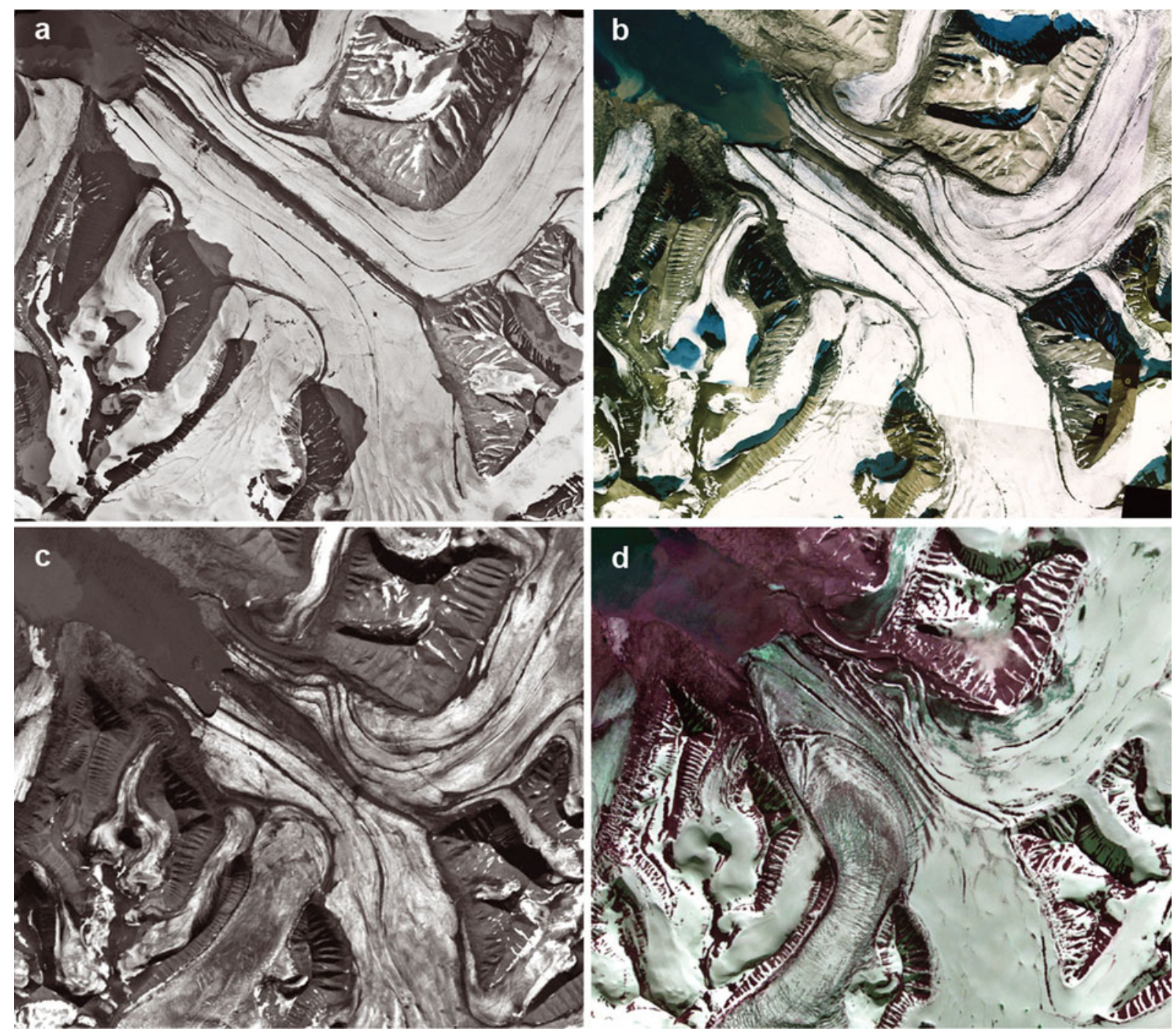

Fig. 3. Recent evolution of Bakaninbreen-Paulabreen: (a) aerial photograph, 1970, prior to both surges (Norsk Polarinstitutt); (b) aerial photograph, August 1990, midway through surge of Bakaninbreen (Norsk Polarinstitutt); (c) ASTER image, July 2003, prior to the surge of Paulabreen; (d) ASTER image, July 2006, after surge of Paulabreen.

$\sim 7.8 \mathrm{~m} \mathrm{~d}^{-1}$, or $\sim 2.8 \mathrm{~km} \mathrm{a}^{-1}$, approximately double the maximum rate of surge propagation on Bakaninbreen. Measured on Advanced Spaceborne Thermal Emission and Reflection Radiometer (ASTER) images from July 2003 and July 2005, the moraine loop of the small glacier Sokkbreen (Fig. 1) was displaced $\sim 1.4 \mathrm{~km}$, corresponding to a mean ice velocity of $\sim 1.6 \mathrm{~m} \mathrm{~d}^{-1}$, or $\sim 0.7 \mathrm{~km} \mathrm{a}^{-1}$. The surge front arrived at the terminus in early April 2005, and between then and August 2005 the glacier front advanced at a mean rate of $4.8 \mathrm{~m} \mathrm{~d}^{-1}$. Surge termination occurred sometime between December 2005 and February 2006. The total advance was $1.9 \mathrm{~km}$. Saturated till was widely exposed around the glacier margins at the end of the surge, and, given the common geological, geographical and climatic environment of Paulabreen and Bakaninbreen, it is likely that Paulabreen surged by the thermally regulated, soft-bed surging mechanism proposed by Fowler and others (2001) and Murray and others (2003).

Similarly to the 1985-95 surge of Bakaninbreen, the lateral margin of the Paulabreen surge closely followed the medial moraine. At the maximum extent of the surge, the boundary between surging and non-surging ice (delineated by the region of heavy crevassing) trended obliquely down- glacier from the confluence of Skobreen and Paulabreen to the medial moraine, whereupon it turned sharply downglacier (Fig. 3d). For the first $2 \mathrm{~km}$, the surge did not extend across the medial moraine, which remained in its pre-surge position. Farther down-glacier, however, the moraine was progressively displaced to the right (relative to glacier flow), with a maximum lateral displacement of $350 \mathrm{~m}$ near the terminus. Crevasses extend across the displaced moraine, affecting a wedge-shaped area of Bakaninbreen with a maximum width of $150 \mathrm{~m}$ at the terminus.

The two glaciers therefore behaved independently during their recent surge history. The 1985-95 surge was confined entirely to Bakaninbreen, and Paulabreen was not affected. Conversely, the 2003-05 surge affected only Skobreen and Paulabreen. The fact that Paulabreen was not activated during the Bakaninbreen surge is particularly notable, since the former glacier was dramatically activated by the surge of a tributary glacier only 10 years later. The independent surge behaviour of Bakaninbreen and Paulabreen thus strongly suggests that the medial moraine delineates the position of an effective barrier between them, which acts to constrain the lateral propagation of surging ice. 


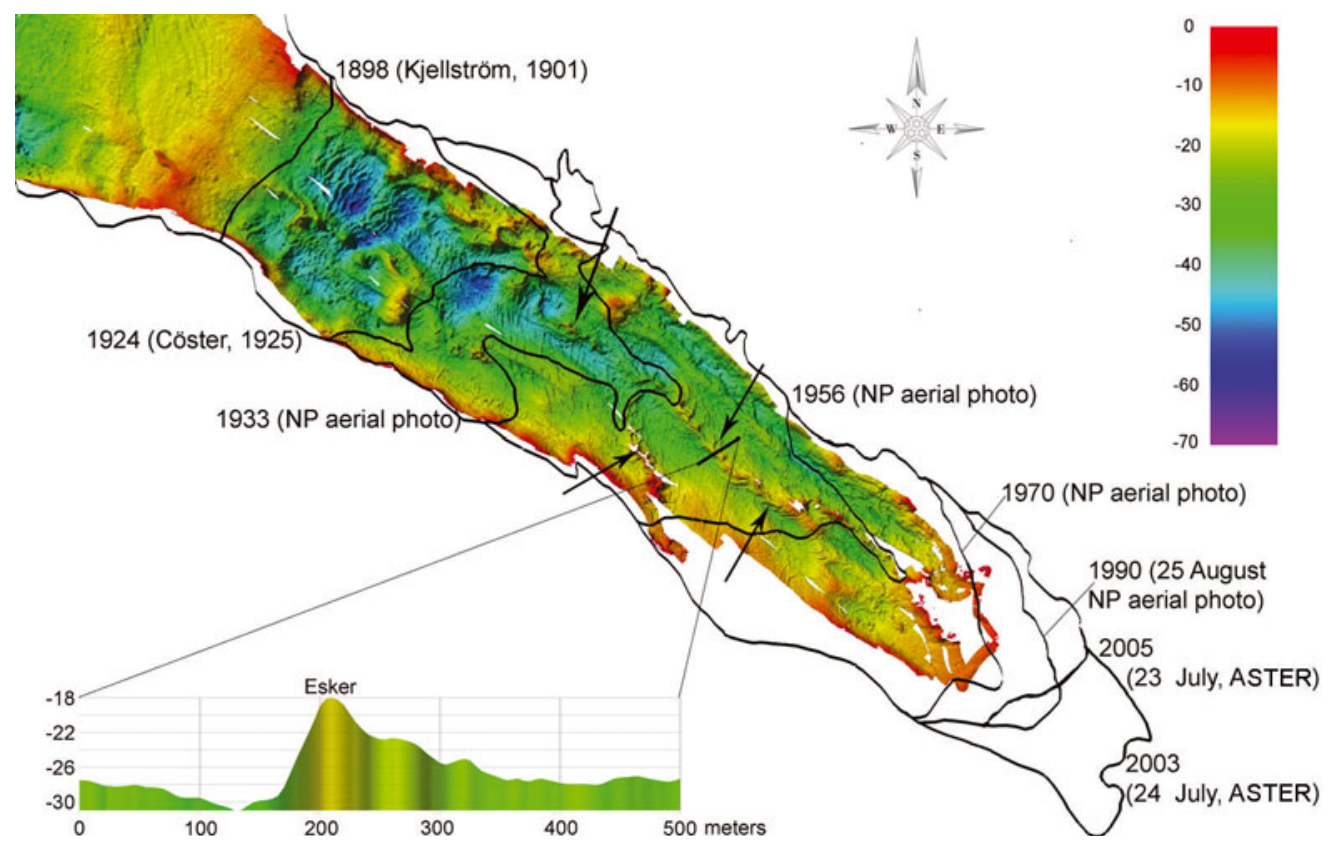

Fig. 4. Bathymetry of Rindersbukta, and documented ice-front positions. The eskers described in the text are arrowed. Note the correspondence between the position of the eskers and deep embayments in the former calving fronts.

\section{EVIDENCE FOR A SUBGLACIAL CONDUIT BETWEEN BAKANINBREEN AND PAULABREEN}

A $250 \mathrm{kHz}$ swath bathymetric survey of Rindersbukta (Ottesen and others, 2008) revealed a major meandering ridge on the fjord floor, extending from close to the present glacier terminus to close to the 1898 glacier limit (Fig. 4). The ridge is sharp-crested, $5-10 \mathrm{~m}$ high and is overprinted by recessional moraine ridges. A second, confluent ridge trends northward from the southwest shore of Rindersbukta, just south of the point where the former tributary glacier Scheelebreen flowed into the fjord. Historical maps and photographs of Paulabreen show that the positions of both ridges coincide with persistent deep embayments in the ice front, varying from narrow notches up to $900 \mathrm{~m}$ long to more open V-shapes. In our experience, embayments in the fronts of tidewater glaciers in Svalbard are typically associated with upwellings of turbid meltwater, marking the location of effluxes from subglacial conduits. Upwelling water undercuts the ice margin, locally enhancing calving and margin retreat. The association between the embayments and upwellings is supported by observations made by Cöster (1925), who reported water emerging from the back of two embayments in the margin of Paulabreen in 1924. The correspondence between the location of the fjord-floor ridges, ice-front embayments and observed water efflux points leads us to conclude that the ridges are eskers, and mark the position of persistent subglacial conduits (see also Ottesen and others, 2008). The efflux points of the main conduit (i.e. the deepest point of the embayments) were consistently located at the terminus of the medial moraine between Paulabreen and Bakaninbreen.

To determine whether a subglacial conduit exists at the upper end of the Bakaninbreen-Paulabreen medial moraine, the glacier confluence was visited in September 2007. A conduit entrance was discovered in the floor of a large hollow on the glacier surface at the up-glacier end of the moraine (marked ' $C$ ' in Fig. 1). The conduit was entered in April 2008. A steep drop of $10 \mathrm{~m}$ led directly to the upper end of a Nye channel cut in bedrock, which consisted of thin-bedded sandstones and shales (Fig. 5a). The lowermost 1-2 $\mathrm{m}$ of the glacier ice had high debris content (including clasts and bands of silt 'clots'), and was frozen to the bed. The Nye channel was box-shaped, 3-5 $\mathrm{m}$ wide and typically $4 \mathrm{~m}$ deep. The height of the ice roof above the top of the Nye channel varied from $\sim 1$ to $\sim 10 \mathrm{~m}$ (Fig. 5b). The conduit was followed for $100 \mathrm{~m}$ downstream until progress was abruptly halted by the collapse of thin ice overlying deep water. The accessed part of the channel had a meandering planform and a stepped long profile, with gently sloping sections separated by steep steps up to a few metres high.

Access was also gained to two feeder passages on the Paulabreen side, one near the upper end of the Nye channel and the other $\sim 90 \mathrm{~m}$ down-glacier of the entrance. Both passages consisted of narrow, incised canyons graded to the Nye channel. The upper passage was surveyed for $200 \mathrm{~m}$ and took the form of a meandering canyon typically $10 \mathrm{~m}$ deep. For much of its length, the passage floor was incised $\sim 1-2 \mathrm{~m}$ into the glacier bed. The roof consisted of masses of snow or icicles plugging the upper levels of the canyon, or 'canyon sutures' formed where opposing walls have been brought into contact by ice creep. This passage continued, but was not surveyed due to time constraints. The lower feeder passage averaged $0.5 \mathrm{~m}$ wide and $7 \mathrm{~m}$ high. Our survey was terminated $\sim 15 \mathrm{~m}$ from the main channel at a vertical nick point, but the passage continued above. The two feeder passages are interpreted as 'cut-and-closure' conduits formed by the incision of supraglacial streams followed by closure of the upper levels by a combination of blown snow, meltwater refreezing and ice creep. The characteristics of cut-and-closure conduits have been described in detail by Gulley and others (2009). In September 2007, water was also seen to enter the head of the Nye channel from a supraglacial channel draining the Bakaninbreen side. The catchment of this channel is small, however, and most water entering the Nye channel is routed via the upper feeder passage on the Paulabreen side. 

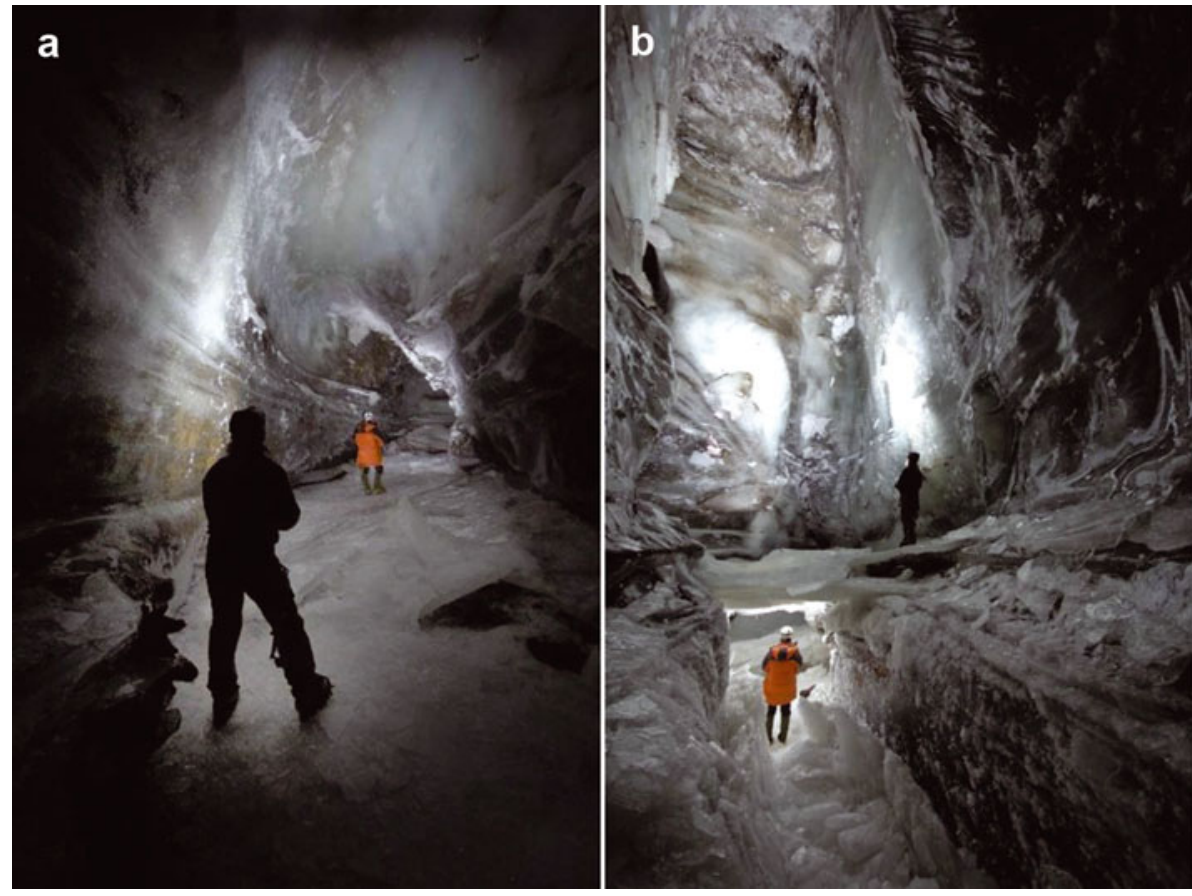

Fig. 5. (a) Nye channel below the confluence of Paulabreen and Bakaninbreen. (b) Another section of the Nye channel, with tall ice-walled canyon above. The figure on the right is standing on a sub-horizontal rock bench, level with the neighbouring glacier bed.

The presence of water in the conduit in April 2008, in very cold weather, leads us to conclude that water may persist year-round, preventing complete conduit closure during the winter. This means that the conduit can be reactivated each summer when surface meltwater enters its upper end, even though at least part of the adjacent bed is below the pressure-melting point. We have frequently encountered englacial and subglacial water pockets in cold ice in wintertime in Svalbard, and attribute its presence to either solute enrichment during partial freezing (cf. Hodson and others, 2005) or inefficient heat loss by conduction into the surrounding ice and bed (cf. Murray and Porter, 2001). It is notable in this respect that the subglacial conduit persisted during a long period during which both Paulabreen and Bakaninbreen were quiescent, when much of the bed was presumably below the pressure-melting point.

\section{DISCUSSION}

According to Murray and others (2000), surge-front propagation at Bakaninbreen occurred by (1) strain thickening of the ice ahead of the surge front in response to compressive stresses, by a combination of ice creep and overthrusting; (2) warming of the ice and bed by strain heating; (3) injection of pressurized water into the bed ahead of the surge front, increasing basal lubrication; and (4) warming of the bed by refreezing of water injected into thrust faults. Retention of pressurized meltwater at the glacier sole is a necessary condition for maintaining fast flow (e.g. Kamb and others, 1985; Fowler and others, 2001; Harrison and Post, 2003), and slowing of surge-front propagation and surge termination appear to have resulted from the release of water along thrust faults and through the bed.

We hypothesize that the conduit below the Bakaninbreen-Paulabreen medial moraine played a key role in constraining the lateral extent of the surges of the two glaciers. When pressurized water beneath surging ice reached the conduit beneath the medial moraine, basal water could have been discharged efficiently to the glacier terminus. This could have occurred during all seasons of the year, if we are correct in concluding that the conduit is a perennial feature, retaining stored water throughout the winter. By allowing water to escape along the bed below the medial moraine, the conduit would have acted as a lowpressure subglacial corridor between the two glaciers, switching off surge propagation mechanisms (3) and (4). It is notable that the only place where the surge propagated from one flow unit to the other and the moraine displaced laterally was on the lower part of Bakaninbreen during the 2003-05 Paulbreen surge. At this locality, the surface of Bakaninbreen is $\sim 20-30$ m lower than that of Paulabreen, so that transverse compressive stress gradients across the moraine would have been much larger than farther upglacier where the two glacier surfaces are closer in elevation. Limited propagation of the surge across the medial moraine could therefore occur in this zone by mechanisms (1) and (2). Alternatively, the conduit may have been less efficient at evacuating water from the lower glacier, decreasing its effectiveness as a pressure barrier.

If we are correct, it may be asked why discharge of water along the conduit did not lead to surge termination, as appears to have been the case for the 'leaky surge front' described by Murray and others (2000). One possible explanation is that significant water losses to the conduit were confined to a relatively narrow zone, and that elsewhere below the surging part of the glacier production of meltwater by strain heating was able to maintain high basal water pressures.

We believe that the presence of a subglacial conduit below the medial moraine is not fortuitous, because confluences in glacier ablation zones can be expected to be favourable sites for surface-to-bed drainage. Gudmundsson (1997) has shown that ice at confluences is subject to transverse compression and longitudinal extension, the former because of flow 
convergence, and the latter because ice is advected away from the no-slip lateral boundary into a mid-stream position where the restraining effect of lateral drag is reduced. In addition, water supply tends to be relatively high at glacier confluences, where lateral supraglacial drainage systems converge. The combination of stressed ice and a plentiful water supply is conducive to hydrologically assisted fracturing, allowing surface crevasses to penetrate to the glacier bed (Alley and others, 2005; Van der Veen, 2007; Catania and others, 2008; Benn and others, inn press). Alternatively, water can leak along the ice-bed interface below the confluence zone (Huss and others, 2007). It is unclear whether surfaceto-bed drainage at the Bakaninbreen-Paulabreen confluence originally formed by hydrologically assisted fracturing or leakage along the bed. Extensive hoar frost on the passage walls obscured much of the structural detail, making interpretation difficult. Examination of surface structures on aerial photographs, however, supports the idea that water initially entered the glacier down an overdeepened fracture, then incised headward to create the observed feeder passages.

Because of the association between glacier confluences and surface-to-bed drainage, we anticipate that other examples may be found of independently surging flow units within confluent glacier systems. Interestingly, during the 1992/93-95 surge of Sortebræ, East Greenland, surging activity was confined to one flow unit in the early part of the event but spread across the whole glacier at a later stage (Pritchard and others, 2005). The reasons for this pattern are not known, although it suggests that barriers to surge propagation may be effective in some circumstances but break down in others.

\section{ACKNOWLEDGEMENTS}

We are grateful for funding and logistical support from The University Centre in Svalbard (UNIS) and Store Norske Spitsbergen Kulkompani (SNSK). Additional funding was provided by Sigma $\mathrm{Xi}$, the Evolving Earth Foundation, the Cleveland, $\mathrm{OH}$, Grotto Science Fund and the US National Speleological Society. We also thank A. Bergström for assistance during exploration of the subglacial conduit.

\section{REFERENCES}

Alley, R.B., T.K. Dupont, B.R. Parizek and S. Anandakrishnan. 2005. Access of surface meltwater to beds of sub-freezing glaciers: preliminary insights. Ann. Glaciol., 40, 8-14.

Benn, D.I., J.D. Gulley, A. Luckman, A. Adamek and P. Glowacki. In press. Englacial drainage systems formed by hydrologically driven crevasse propagation. J. Glaciol.

Catania, G.A., T.A. Neumann and S.F. Price. 2008. Characterizing englacial drainage in the ablation zone of the Greenland ice sheet. J. Glaciol., 54(187), 567-578.

Cöster, F. 1925. Results of the Swedish expedition to Spitsbergen in 1924. 1: Quaternary geology of the region around the Kjellström valley. Geogr. Ann., 7, 104-120.

Dowdeswell, J.A. and T.J. Benham. 2003. A surge of Perseibreen, Svalbard, examined using aerial photography and ASTER highresolution satellite imagery. Polar Res., 22(2), 373-383.

Dowdeswell, J.A., G.S. Hamilton and J.O. Hagen. 1991. The duration of the active phase on surge-type glaciers: contrasts between Svalbard and other regions. J. Glaciol., 37(127), 388-400.

Fowler, A.C., T. Murray and F.S.L. Ng. 2001. Thermally controlled glacier surging. J. Glaciol., 47(159), 527-538.

Gudmundsson, G.H. 1997. Ice deformation at the confluence of two glaciers investigated with conceptual map-plane and flowline models. J. Glaciol., 43(145), 537-547.

Gulley, J.D., D.I. Benn, D. Müller and A. Luckman. 2009. A cutand-closure origin for englacial conduits in uncrevassed regions of polythermal glaciers. J. Glaciol., 55(189), 66-80.

Harrison, W.D. and A.S. Post. 2003. How much do we really know about glacier surging? Ann. Glaciol., 36, 1-6.

Hodson, A.J., P.N. Mumford, J. Kohler and P.M. Wynn. 2005. The High Arctic glacial ecosystem: new insights from nutrient budgets. Biogeochem., 72(2), 233-256.

Huss, M., A. Bauder, M. Werder, M. Funk and R. Hock. 2007. Glacier-dammed lake outburst events of Gornersee, Switzerland. J. Glaciol., 53(181), 189-200.

Kamb, B. and 7 others. 1985. Glacier surge mechanism: 19821983 surge of Variegated Glacier, Alaska. Science, 227(4686), 469-479.

Kjellström, O.C.J. 1901. En exkursion för uppmätning af Van Mijen bay under 1898 års svenska polarexpedition. Ymer, 29(H1), 29-34.

Luckman, A., T. Murray and T. Strozzi. 2002. Surface flow evolution throughout a glacier surge measured by satellite radar interferometry. Geophys. Res. Lett., 29(23), 2095. (10.1029/ 2001GL014570.)

Meier, M.F. and A. Post. 1969. What are glacier surges? Can. J. Earth Sci., 6(4), 807-817.

Murray, T. and P.R. Porter. 2001. Basal conditions beneath a softbedded polythermal surge-type glacier: Bakaninbreen, Svalbard. Quat. Int., 86(1), 103-116.

Murray, T., D.L. Gooch and G.W. Stuart. 1997. Structures within the surge front at Bakaninbreen, Svalbard, using ground-penetrating radar. Ann. Glaciol., 24, 122-129.

Murray, T., J.A. Dowdeswell, D.J. Drewry and I. Frearson. 1998. Geometric evolution and ice dynamics during a surge of Bakaninbreen, Svalbard. J. Glaciol., 44(147), 263-272.

Murray, T. and 6 others. 2000. Glacier surge propagation by thermal evolution at the bed. J. Geophys. Res., 105(B6), 13,491-13,507.

Murray, T., T. Strozzi, A. Luckman, H. Jiskoot and P. Christakos. 2003. Is there a single surge mechanism? Contrasts in dynamics between glacier surges in Svalbard and other regions. J. Geophys. Res., 108(B5), 2237. (10.1029/2002JB001906.)

Ottesen, D. and 9 others. 2008. Submarine landforms characteristic of glacier surges in two Spitsbergen fjords. Quat. Sci. Rev., 27(15-16), 1583-1599.

Pritchard, H., T. Murray, A. Luckman, T. Strozzi and S. Barr. 2005. Glacier surge dynamics of Sortebræ, east Greenland, from synthetic aperture radar feature tracking. J. Geophys. Res., 110(F3), F03005 (10.1029/2004JF000233.)

Smith, A.M., T. Murray, B.M. Davison, A.F. Clough, J. Woodward and $\mathrm{H}$. Jiskoot. 2002. Late surge glacial conditions on Bakaninbreen, Svalbard, and implications for surge termination. J. Geophys. Res., 107(B8), 2152. (10.1029/2001JB000475.)

Stuart, G., T. Murray, A. Brisbourne, P. Styles and S. Toon. 2005. Seismic emissions from a surging glacier: Bakaninbreen, Svalbard. Ann. Glaciol., 42, 151-157.

Sund, M. 2006. A surge of Skobreen, Svalbard. Polar Res., 25(2), 115-122.

Van der Veen, C.J. 2007. Fracture propagation as means of rapidly transferring surface meltwater to the base of glaciers. Geophys. Res. Lett., 34(1), L01501. (10.1029/2006GL028385.) 